\title{
The Effect of Responsibilitas, Leadership, on Job Performance of High School at North Jakarta
}

\author{
Hamri $^{1}$, M Asmawi ${ }^{2}$, Rasyid $^{3}$ \\ $\left\{{ }^{1}\right.$ hamri@unj.ac.id, ${ }^{2}$ mochasmawi@unj.ac.id, ${ }^{3}$ unifahrasyid@unj.ac.id $\}$ \\ 1,2,3 Universitas Negeri Jakarta, Jakarta, Indonesia
}

\begin{abstract}
The purpose of this study was to describe and analyze the influence of responsibility, leadership on job performance. This research used a quantitative approach with survey method. The sample of this research is the whole 120 teachers in High School at North Jakarta is done randomly. The results of the research showed that (1) there is a positive direct influence on responsibility for performance; (2) there is a positive direct effect of leadership on performance; (3) there is a positive direct influence on responsibility for leadership; (4) there is a positive indirect effect of responsibility for performance through leadership. To improve performance, it is necessary to increase responsibility, and leadership.
\end{abstract}

Keywords: Responsibility, Leadership, Job Performance

\section{INTRODUCTION}

The performance of teachers in North Jakarta Public High Schools must always be improved to produce quality education quality. Having a teacher who performs well, will have implications for the learning process in the classroom in educating students, which in turn can improve the quality of students. Likewise, conversely, teachers who perform poorly will have an impact on the quality of students. Therefore improving teacher performance can be supported by several factors such as teachers must have responsibility in work, leadership of school principals.

Based on the initial survey, it was found that there were several problems related to the performance of North Jakarta High School teachers including; not being able to optimally develop teaching materials properly, teaching materials only focus on teaching material books so that the teacher does not have the ability to adapt teaching materials and teaching materials according to the needs of students, not according to the conditions of students and not in accordance with work life.

Other problems that arise, teachers have not optimally designed teaching materials well, do not develop their creativity and even seem to only focus on completing teaching material. Not evaluating student learning methods, not paying attention to how to teach well related to the application of teaching approaches and methods, not understanding the ability of students to receive teaching material, and not paying attention to students' ability to understand teaching material so that mastery and understanding of teaching material for students is not optimal.

Furthermore, the lack of optimal teacher performance can also be seen from the quality of work shown by North Jakarta High School teachers. This can be seen that the teacher is often 
late in teaching in the classroom, often completing teaching before the time is over, even not paying attention to class conditions and the readiness of students to receive teaching materials. Even though paying attention to the readiness of students in receiving teaching material is very important to see the effectiveness of teaching in the classroom.

Furthermore, the problem that arises when researchers conduct surveys in the field is that teachers only complete their main tasks as teaching staff in the classroom, only focus on students' cognitive abilities and pay little attention to aspects of student character so that some students are still involved in brawls between students. Related to the research done, there are several variables that need to be explained; Responsibilities, and leadership.

Basically performance is the level of achievement of the implementation of teacher duties based on their authority and responsibility. To achieve good performance is certainly not an easy thing. This is due to the number of things or aspects that affect the level of performance of a teacher, both in terms of organizational mechanisms, group mechanisms, individual characteristics, and individual mechanisms. According to Sony and Mekoth that "performance, in general, refers to behavior that is relevant to organizational goals and under individual control" [1].

While Melanie Ohme and Zacher that "Performance is one of the most important results in the context of work, it has been defined as a measurable ability of work behavior that is under control and contributes to organizational goals" [2]. According to Ghani, et. al, that "performance is one of the important elements that provide goals and methods to achieve the organization's mission" [3]. According to Mohamad and Jais that "performance is the total value expected of individuals in carrying out a job. In addition, each individual has the quality and quantity of work" [4]. Furthermore, according to Yoon-Suk Hwang et. al, that performance is essentially, teachers are able to improve students ' academic outcomes [5].

This shows that individual performance is largely determined by motivation and desires and the ability to do work ". Although the leaders must take corrective action to restore it if there is an imbalance between the established work standards and the level of work achieved.

Responsibility is another term of responsibility. Responsibility is an action that is very important to do in everyday life because without responsibility, then everything will be chaotic. However responsibility becomes something very important in his main life in the world of education. According to Mergler and Shield that "the responsibility is determined based on causality (what has been done) and hope (what should have been done)" [6] .

According to Helker and Wosnitza that "responsibility is seen as an individual quality, which is reflected in the realization and emotional experience needed to do a job and readiness to realize responsible behavior" [7]. So that the responsibility is not only the completeness of a job but also more embedded in the issue of character and awareness of the main awareness of a teacher in improving the quality of education. According to Ilona Semradova and Sarka Hubackova that responsibilities are usually defined as political, criminal, legal and ethical categories that reveal about the relationship between the actions and the consequences of any action performed [8].

Responsibility is part of an appropriate and effective way of making decisions, it should mean setting the best choices within the boundaries of social norms and commonly given expectations, to enhance positive human relations. In decision making it is closely related to the attitude of responsibility because the results of these decisions will certainly provide an effect in the world of education. With this attitude of responsibility can improve achievement in school, as well as learning requires great personal responsibility.

Leadership is a topic that attracts many people and is defined in many ways. According to Elbaz and Haddoud that "leadership is an important and dynamic component in realizing 
organizational satisfaction and performance. Effective leadership is seen as the beginning of job satisfaction, and as a vital factor for organizational success" [9]. Leadership arises and develops as a result of automatic interactions between leaders and individuals led. Since the beginning of the formation of a social group, a person or a number of people among their citizens have a more active role than their peers, so that the person or some people appear more prominent than others.

A leader may have a variety or more than one power inherent in him, whose essence can be used to control quality or leadership according to his authority. A person must have the skills and strengths, especially the excess skills in one field so that he is able to influence other people to jointly carry out certain activities, in order to achieve one or several goals.

According to Player et. al, that "effective leadership can realize the school's vision, provide support to teachers, improve teacher performance and enforce rules" [10]. Certain leadership will greatly influence the leadership style, namely leaders who carry out their leadership functions with all their philosophy, skills and attitudes. Furthermore, according to Pina, et. al that "leadership can directly affect schools, classroom conditions and teachers, which in turn can affect indirect learning conditions of students" [11]. The leader can focus on interpersonal relationships. In this case, it includes mutual trust, respecting subordinate ideas, building cooperation, being sensitive to the needs and welfare of subordinates.

\section{RESEARCH METHOD}

The method in this study is a survey that will be analyzed using path analysis. The questionnaires used to obtain research data consisted of three variables, namely: responsibility $\left(\mathrm{X}_{1}\right)$, leadership $\left(\mathrm{X}_{2}\right)$, and teacher performance $(\mathrm{Y})$. Inferential analysis uses path analysis. This research was conducted in North Jakarta State High School in the sample in this study amounted to 120 people. But before using path analysis, the analysis requirements test was carried out first, namely the normality test, significance test, and linearity. Whereas to calculate the path coefficient using the correlation coefficient of each causal relationship.

\section{RESULTS AND DISCUSSION}

The results obtained after conducting a model analysis are used as a basis in answering hypotheses and drawing conclusions in this study. Explanation of the answers to these hypotheses can be described as follows:

First hypothesis, positive direct effect of responsibility on performance. The results of the analysis of the first hypothesis resulted in the finding that responsibility has a direct positive effect on performance. From the data of the calculation for the preparation of the regression equation model between the performance and responsibility in appendix 5 , the regression constants $\mathrm{a}=89.34$ and the regression coefficient $\mathrm{b}=0.31$. Thus the relationship between the simple regression equation model is $\hat{\mathrm{Y}}=89.34+0.31 \mathrm{X}_{1}$. Before the regression equation model is further analyzed and used to draw conclusions, first test the significance and linearity of the regression equation. Regression equation $\hat{\mathrm{Y}}=89.34+0.31 \mathrm{X}_{1}$, for the significance test obtained $\mathrm{F}$ count 24.71 greater than $F_{\text {table }}(0.05 ; 1: 118) 3.92$ at $\alpha=0.05$. Because $F$ count $>F_{\text {table, }}$, the regression equation is stated to be very significant. For the linearity test obtained $F$ count of 0.98 smaller than $\mathrm{F}_{\text {table }(0.05 ; 29: 89)}$ of 1.59 at $\alpha=0.05$. Because $\mathrm{F}_{\text {count }}<\mathrm{F}_{\text {table, }}$, the distribution of estimated points forms a linear line can be accepted. In research conducted by Kirsten Schweinberger that teachers have a responsibility in enhancing the motivation and achievement of students [12]. 
Second hypothesis, positive direct effect of leadership on performance. The results of the second hypothesis analysis yield findings that leadership has a direct positive effect on performance. From the calculation data for the preparation of the regression equation model between performance and leadership in appendix 5, the regression constants a $=92.72$ and the regression coefficient $b=0.27$. Thus the relationship of the simple regression equation model is $\hat{Y}=92.72+0.27 X_{2}$. Before the regression equation model is further analyzed and used to draw conclusions, first test the significance and linearity of the regression equation. Regression equation $\hat{Y}=92.72+0.27 X_{2}$, for the significance test obtained $F_{\text {count }} 23.81$ greater than $F_{\text {table }}(0.05$; 1: 118) 3.92 at $\alpha=0.05$. Because $F$ count $>F$ table, the regression equation is stated to be very significant. For the linearity test obtained $F_{\text {count }}$ of 1.42 smaller than $F_{\text {table }}(0.05 ; 32: 86)$ of 1.58 at $\alpha$ $=0.05$. Because $\mathrm{F}_{\text {count }}<\mathrm{F}$ table, the distribution of estimated points forms a linear line can be accepted. In the study, Brenda E. Morrison, and Dorothy Vaandering in this journal have been suggested that the leadership has relevance to the performance [13].

Third hypothesis, positive direct effect of responsibility on leadership. The results of the sixth hypothesis analysis provide findings that responsibility has a direct positive effect on leadership. The path coefficient value of responsibility for leadership is 0.208 with a calculated $t$ value of 2.32. Because the coefficient of $t_{\text {count }}$ is greater than the value of $t_{\text {table }}$ at $\mathrm{dk}=118$ for $\alpha=0.05$ at $1.98, \mathrm{H} 0$ is rejected and $\mathrm{H} 1$ is accepted, which means there is a positive direct effect of the responsibility variable on the leadership variable which is very significant. In research conducted by Marshall the leadership has relevance to the responsibility [14]. According to David Knights, et, al that leadership will not be accomplished properly, if there is no effort to improve themselves and have no sense of responsibility [15].

Fourth hypothesis, positive indirect impact of responsibility on performance through leadership. The indirect effect of responsibility for performance through leadership is the product of three path coefficients, namely: the path coefficient of responsibility to leadership $\left(\beta_{21}\right)$. The amount of indirect influence responsibility for performance through leadership is: $(0.208)(0.243)=0.013$. So that the influence of total responsibility on performance is 0.294 through leadership. Research conducted by Ohme and Zacher about good performance can improve your career. The difference in research done is not to study the career [2].

\section{CONCLUSIONS}

This study is intended to look for factors that can influence the performance of teachers in North Jakarta State Senior High School including responsibility, and leadership. Responsibility directly positively affects the performance, direct positive leadership to the performance, the responsibility directly positively affects the leadership, the responsibility of indirect effect positively to performance through leadership.

\section{REFERENCES}

[1] M. Sony and N. Mekoth, "The Relationship between Emotional Intelligence, Frontline Employee Adaptability, Job Satisfaction and Job Performance," J. Retail. Consum. Serv., vol. 30, no. 2, pp. 20-32, 2016.

[2] M. Ohme and H. Zacher, "Job Performance Ratings: The Relative Importance of Mental Ability, Conscientiousness, and Career Adaptability," J. Vocat. Behav., vol. 32, no. 1, pp. 1-32, 2015.

[3] N. Maisarah, A. Ghani, N. Sara, N. Muhamad, and N. Saiful, "Leader' s Personality Traits and Employees Job Performance in Public Sector, Putrajaya," Procedia Econ. 
Financ., vol. 37, no. 16, pp. 46-51, 2016.

[4] M. Mohamad and J. Jais, "Emotional Intelligence and Job Performance : A Study Among Malaysian Teachers," Procedia Econ. Financ., vol. 35, no. 2, pp. 674-682, 2016.

[5] Y. Hwang, B. Bartlett, M. Greben, and K. Hand, “A Systematic Review of Mindfulness Interventions for in-Service Teachers: A Tool to Enhance Teacher Wellbeing and Performance," Teach. Teach. Educ., vol. 64, no. 2, pp. 26-42, 2017.

[6] A. Mergler and P. Shield, "Development of the Personal Responsibility Scale for adolescents," J. Adolesc., vol. 51, no. 1, pp. 50-57, 2016.

[7] K. Helker and M. Wosnitza, "The Interplay of Students' and Parents' Responsibility Judgements in the School Context and their Associations with Student Motivation and Achievement," Int. J. Educ. Res., vol. 76, no. 1, pp. 34-49, 2016.

[8] I. Semradova and S. Hubackova, "Teacher Responsibility in Distance Education," Procedia - Soc. Behav. Sci., vol. 217, no. 2, pp. 1-7, 2016.

[9] A. Mohamed and E. Lecturer, "The Role of Wisdom Leadership in Increasing Job Performance: Evidence from the Egyptian Tourism Sector," Tour. Manag., vol. 63, no. 2, pp. 66-76, 2017.

[10] D. Player, P. Youngs, F. Perrone, and E. Grogan, "How Principal Leadership and Person-Job Fit are Associated with Teacher Mobility and Attrition," Teach. Teach. Educ., vol. 67, no. 1, pp. 1-9, 2017.

[11] R. Pina, I. Cabral, and J. Matias, "Principal`s Leadership on Students ` Outcomes," Procedia - Soc. Behav. Sci., vol. 197, no. 2, pp. 1-6, 2015.

[12] K. Schweinberger, C. Quesel, S. Mahler, and A. Höchli, "Studies in Educational Evaluation Effects of Feedback on Process Features of School Quality: A Longitudinal Study on Teachers' Reception of School Inspection of Swiss Compulsory Schools," Stud. Educ. Eval., vol. 55, no. 2, pp. 75-82, 2017.

[13] B. E. Morrison and D. Vaandering, "Restorative Justice: Pedagogy, Praxis, and Discipline,” J. Sch. Violence, vol. 11, no. 2, pp. 138-155, 2012.

[14] S. Gregory Marshall, "Educational Middle Change Leadership in New Zealand: The Meat in the Sandwich," Int. J. Educ. Manag., vol. 26, no. 1, pp. 1-26, 2012.

[15] D. Knights, "Leadership, Ethics and Responsibility to the Other," J. Bus. Ethics, vol. 12, no. 2, pp. 1-18, 2016. 